\title{
Középkori leletek Nagyberki-Szalacskáról I.
}

\author{
VARGA MÁTÉ \\ Rippl-Rónai Múzeum \\ H-7400 Kaposvár, Fő u. 10., e-mail: vargamate12@gmail.com
}

VARGA, M.: Medieval finds from Nagyberki-Szalacska I.

Abstract: We don't know much about the medieval history of Szalacska up to this point. We only have some medieval stray finds from here. In the course of excavations of the 1980's many medieval finds turned up. We can conclude that Szalacska was a built-up area during the 10-17th centuries on the score of research up to this point. The medieval church of the village Szalacska stood on the south part of the prehistoric fortress and we can presume the existence of a medieval fortress also on the site.

Keywords: medieval church, cemetery, settlement, silver coins, bronze anvil, bronze mace, ceramics, iron objects, fortress

\section{Kutatástörténet}

Nagyberki-Szalacska a régészetben, illetve a régészeti szakirodalomban már jól ismert. ${ }^{2}$ Azonban eddig középkori történetéről, és középkori leletekről nem igazán esett szó. ${ }^{3}$ Eme dolgozat célja, hogy az eddig kevésbé tárgyalt korszak leleteit bemutassa, ezáltal is adatokat szolgáltatva a terület középkori történetéhez, valamint a középkori magyar régészethez.

Nagyberki jelenlegi közigazgatási területéhez tizenhat nyilvántartott régészeti lelőhely tartozik. Ezek közül kiemelkedik a szalacskai várhegy és környezete, ahol találunk szórványleleteket és kincsleleteket

$1 \mathrm{Az}$ angol nyelvű absztrakt helyesírási hibáinak javítását $\mathrm{M}$. Aradi Csilla (BMK KÖl) végezte, míg a tanulmány végén olvasható német nyelvű szöveg Ujhelyi Nóra (ELTE BTK) fordítása, ezúton is köszönöm mindkettőjüknek a segítséget.

2 Szakirodalmi áttekintés a teljesség igénye nélkül: Rómer Flóris: Compte-rendu de la VIIle session á Budapest. Budapest, 1887 114-121., Darnay Kálmán: Kelta pénzverő és öntőmühely Szalacskán. Archaeologiai Értesítő 26. (1906) 416-433., M. Kabay Éva: A szalacskai koravaskori tumulusok anyaga a Magyar Nemzeti Múzeumban. Folia Archaeologica XII. (1960) 45-59., Kemenczei Tibor: Előzetes jelentés a nagyberki-szalacskai halomásatásokról. Somogyi Múzeumok Közleményei 1. (1973) 229-333., Kemencze Tibor: Beszámoló a nagyberki-szalacskai 1974. évi ásatásról. Somogyi Múzeumok Közleményei 2. (1975) 163-171.

3 Lásd: A Somogy Megyei Múzeumok Igazgatóságának beszámoló jelentése az 1982-ben végzett munkáról. Somogyi Múzeumok Közleményei 5. (1982) 165., Mészáros Balázs: A Somogy Megyei Múzeumok Igazgatóságának beszámoló jelentése az 1983-ban végzett munkáról. Somogyi Múzeumok Közleményei 6. (1983) 188. Mészáros Balázs: A Somogy Megyei Múzeumok Igazgatóságának 1984. évi beszámoló jelentése. Somogyi Múzeumok Közleményei 7. (1985) 213. Középkori leletekröl egyikben sem esik szó.

Németh Péter Gergely: Nagyberki-Szalacska. Somogyi Múzeumok Közleményei 19. (2010) 28. Ebben már említésre kerül, hogy az Árpád-kortól a késő középkorig keltezhetőek az objektumok és leletek, valamint szó esik a középkori templomról és a körülötte lévő temetkezésekröl is. az újkőkorból, a bronzkorból, a vaskorból és a római korból, éremleletet a római korból, ismeretlen korú sírt és temetőt, Hallstatt-kori és római kori temetőt, halomsírokat, rézkori, bronzkori, vaskori kelta, római kori település nyomokat, több korszakú földvárat, kelta éremverő műhely maradványait, valamint középkori település nyomokat, középkori templomot és templom körüli temetöt. ${ }^{4}$ A fentebb felsoroltak közül jelenleg az utóbbiakkal szeretnénk többet foglalkozni. A korábbi feltárások többnyire a halmok területére, illetve a szórványosan előkerült tárgyak leletmentésére koncentrálódtak. Középkori leletek korábban is kerülhettek elő, de ezekről nem sok tudomásunk van. ${ }^{5} \mathrm{~A}$ várhegyen a tervszerű régészeti kutatások az 1980-as években kezdődtek meg.

Szórványleletként került be a múzeumba egy középkori béklyóként meghatározott tárgy (1. ábra). A Feketegyűjteményből ${ }^{6}$ kerültek be középkori érmék a múzeumba. Azonban ezen érmek származási helye bizonytalan, így egyáltalán nem biztos, hogy Szalacskáról jutottak

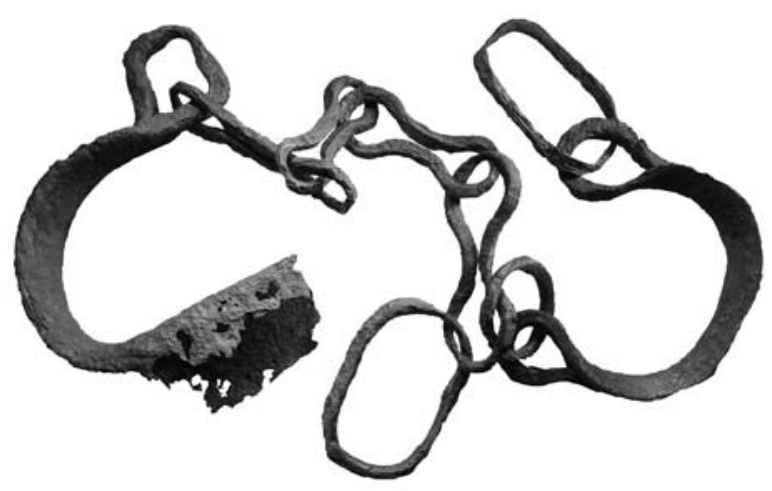

1.ábra: Középkori vas béklyó (fotó: Balla Krisztián)

4 KÖH-azonosító: 47869 (Szalacska földvár) és 47862 (Szalacskaközépkori templom)

5 A kaposvári Rippl-Rónai Múzeum gyüjteményébe kerültek be korábban innen származó középkori leletek, ezek ismertetése lejjebb fog megtörténni.

6 Fekete József (Mosdós, 1893 - Kaposvár, 1970): festőművész, tanár, helytörténész. Mosdóson élt, a nagyberki általános iskolában tanított évtizedeken keresztül. Nagyberki, Szalacska és Mosdós történetét kutatta, emellett sok leletet összegyüjtött. Az általa felhalmozott tárgyak egy része halála után a kaposvári múzeumba kerültek, azonban sok lelet már pontosan nem azonosítható, hogy honnan is származik. Lásd: Frech 2006. 24-25. 
a magángyűjteménybe. ${ }^{7}$ Szintén a Fekete-gyüjteményből került be a múzeumba számos középkori vas-, és bronztárgy, azonban ezek többségének származása is bizonytalan. Ezek eredetének felkutatása még zajlik, így ezekröl a későbbiekben számolunk be. Szám Anna egyetemi hallgató 1964-ben a területen folytatott helyszínelést, ahol sok őskori, Hallstatt-kori, La Tène kultúra korabeli, bronzkori, római, „barbár” (népvándorlás kori?) és középkori kerámiát is gyüjtött, amelyeket eljuttatott a kaposvári múzeumba. ${ }^{8} \mathrm{~A}$ Darnay-leltárkönyvben ${ }^{9}$ pontosabb lelőhely megnevezés nélkül az alábbi leletek szerepelnek Szalacskáról: „igen sok” vassarkantyú, kengyel, patkó, nyílcsúcs, kés, lándzsa. ${ }^{10}$

A középkori településről az alábbi írott forrásokkal rendelkezünk jelenleg ${ }^{11}$ : a terület 1524-ben a somogyvári apáté. Ekkor egy gyaláni birtokperben tünik fel az apát Szabó Gál nevű szalacskai (Zolachka) jobbágya. ${ }^{12} 1535$-ben Török Bálint 300 forintért bérbe veszi Somogy megye tizedeit Máté apáttól és konventjeitől egy évre. Az oklevélben megnevezik ezeket a falvakat, itt említik Szalacskát. ${ }^{13}$ 1542-ben kettő és fél - Török Bálintnak - adófizető portát írtak össze, valamint öt darab portát, amik nem fizetnek (szegénységük miatt). ${ }^{14} \mathrm{Az}$ 1554-es török defterben hat adózót $^{15}$ írtak össze Szalacskán, míg a közvetlenül utána említett Váralja (Várolja) ${ }^{16}$ részen három adózót (ezek a települések a szentmártoni - ma Felsőszentmárton - náhije-be tartoztak). 1555 után változott a közigazgatási beosztás, ekkor Berki és környéke a (török) koppányi náhije-be tartoztak. ${ }^{17}$ Szalacskán 1565-ben és 1582-ben is 10-10 adózót említenek, míg Váralján ugyanezen időpontokban három, illetve öt adózót írtak

7 Találunk köztük II. Géza és II. Béla érmeket, „Moneta regis... (Slavon dénár) K. Kálmán idejéböl. 2 db Szalacskáról, 1 db Szabadiból. Tar Józsi nagyanyjától." (az érmek nincsenek meg), III. Béla rézpénzét ( $\mathrm{CNH}$ 98., $4 \mathrm{db}$ ), III. Béla „arab feliratú” pénze (nincs meg), Károly Róbert ezüstdenárt ( $\mathrm{CNH}$ II. 8., nincs meg), Károly Róbert ezüstdenárt (CNH II. 54.A, 3 db, nincs meg), I. Lajos szerecsenfejes denáriát (CNH II. 89. A.), I. Ulászló denárt, török akcsét (nincs meg), II. Mátyás, II. Ferdinánd, I. Lipót, II. Rákóczi Ferenc, I. József, II. Lipót, I. Ferenc és V. Ferdinánd érmeit is.

8 RRM Régészeti Adattár IV/47/39. számú jelentésében olvasható. A középkori leletek nincsenek meg a múzeumban, de elképzelhető, hogy valójában nem is kerültek be.

9 Darnay Kálmán (Sümeg, 1864 - Sümeg, 1945): író és régész volt, Sümeg környékén több jelentős ásatást is folytatott, illetve a saját gyűjteményéből alakult meg az Állami Darnay Múzeum. Ásatásokat folytatott Szalacskán is, és több leletet összegyűjtött. A múzeum gyüjteményét később a keszthelyi Balatoni Múzeumba szállították. İgy néhány szalacskai tárgy jelenleg ott található meg. Továbbá lásd: Németh 1964.

10 Kocztur 1964. 102., Feltehetően korábban ezek is a Darnaygyüjteményben voltak.

11 Az információkért hálás köszönet K. Németh Andrásnak

12 Szakály 1998. 207. 208. pont

13 Sörös - Rezner 1905. 793-794

14 Magyar Országos Levéltár, E 158 Conscriptiones portarum. XLIII/b. Nr. 44. Fol. 458.; Zalachka néven szerepel, valamint feltünik mellette egy Waralya rész is. „Valentinus Thewrek portarum 2,5, Pauperus V.", továbbá Tímár 1976. 54. 1322. pont

15 A forrásokban hane szerepel, amit jobb híján adózónak fordítottak. A hane valójában jobban megfelel a család fogalmának, bár vannak, akik szerint ház, épület jelentéssel bír. Káldy-Nagy 1960. 7.

16 Ezt a falut a szerző Tarrós vagy Cserénfa környékre helyezte, de véleményünk szerint Szalacska mellett keresendö.

17 Csánki 1914. 463 össze. ${ }^{18}$ Váralján 1542-ben lakott egy egytelkes nemes is, név szerint Fekető Benedek. ${ }^{19} 1438-83$ között Berki biztosan Tolna megyéhez tartozott, így valószínű, hogy a tőle nem messze lévő Szalacska is. Az 1573-74. évi török kincstári lajstromban Berki néven szereplő településen három adózó háztartást említenek. ${ }^{20} \mathrm{Az} 1660$. évi pannonhalmi dézsmaváltságjegyzék szerint Csobánc várához tartozott Szalacska. ${ }^{21}$

Sági Károly 1952-es ásatása alkalmával az 1333/3. kataszteri számú telek sarkában egy rom nyomait látta. A népnyelv ezt a részt „török mecset”-nek nevezi. A kőtörmelék mellett középkori téglát is lehetett találni, így Sági már akkor megállapította, hogy a rom nem római korú. Szintén ez évben Sági azonosította, hogy Darnay Kálmán hol találta meg 1906-ban a kincsleletet. A lelettől nyugatra kb. 15 méterre 20 rendszertelen fekvésü, melléklet nélküli csontváz is előkerült.. ${ }^{22}$ Utóbbiakról elképzelhetö, hogy szintén a templom körüli temetőhöz tartozhattak. ${ }^{23}$ 1979-ben a területen Honti Szilvia több ízben is végzett helyszínelést, amikor Pallósi József leletbejelentő több leletet és lelőhelyet mutatott meg. Elmondása szerint a szalacskai szőlöhegyen a Papgödör nevű helyen, Orbán Sándor telkén van egy templomhely. A közelében egy ásott, falazott kút, ahonnan Fekete József tanító sok leletet vitt el. Pallósi elmondta, hogy fiatalabb korában, a templomból még kő-, és téglafalak is álltak. ${ }^{24}$ Szalacskát K. Németh András is említi, mint templomos helyet a középkorban. ${ }^{25}$

$A z$ 1715. és 1720. évi országos összeírásban már nem szerepel Szalacska. Az I. katonai felmérésen (178084 között készült) Szalacska néven jelenik meg, de nem mint lakott település, hanem szőlőhegyként ábrázolják a kápolnával együtt. A. II. katonai felmérésen (1806-69 között készült) már „Salatska puszta” néven szerepel, a várhegytöl nyugati irányban helyezkedik el (2. ábra). ${ }^{26}$ Mivel ezeken a térképeken már pusztaként szerepel, így valószínü, hogy a török hódoltság idején néptelenedhetett el, és azután már nem telepedtek meg újból az emberek Szalacskán. A várhegyet - ahogy a térképeken is látszik - szőlőhegyként használják a későbbi időkben. Szalacskán egy hosszú életű megtelepedéssel számolhatunk, hiszen egészén a 10. századtól a 17. századig létezhetett. Amikor a kápolnát - valószínüleg 1773-ban

18 Káldy-Nagy 1960. 37., Szalacska: „Ágoston kovács, Sebők János, Tód Gál, Szabó Kelemen, Hájós Imre, Pál András”; Váralja: „Farkas János, Balázs Benedik, Füredi Mihál"

19 Tímár 1976. 56. 1385. pont és 93. 847. jegyzet. „Waralya. Benedictus Fekethew nobilis unius sessionis pauper est."

20 Csánki 1914. 117

21 Csánki 1914. 96.

22 MNM Adattár 81.Sz.I., RRM Régészeti Adattár IV/47/23-24., Kocztur 1964. 102.

23 Ha a Darnay-féle ásatás a mai kápolnától déli-délkeleti irányban volt, akkor a középkori templom ettöl jóval délebbre található (200300 méter), így nem valószínü, hogy a középkori temető eddig elérjen.

24 RRM Régészeti Adattár IV/47/111-112.

25 K. Németh 2011. 111. Nagyberki és környéke a középkorban hol Somogy megyéhez, hol Tolna megyéhez tartozott, ezért is szerepel a középkori Tolna megyei templomok között.

26 Továbbá Frech József: Fejezetek Nagyberki történetéből. Nagyberki, 2001., Frech József: Szalacska: egy földvár története. Nagyberki, 2010., A II. katonai felmérésen a puszta a várhegytől nyugati irányban található. 


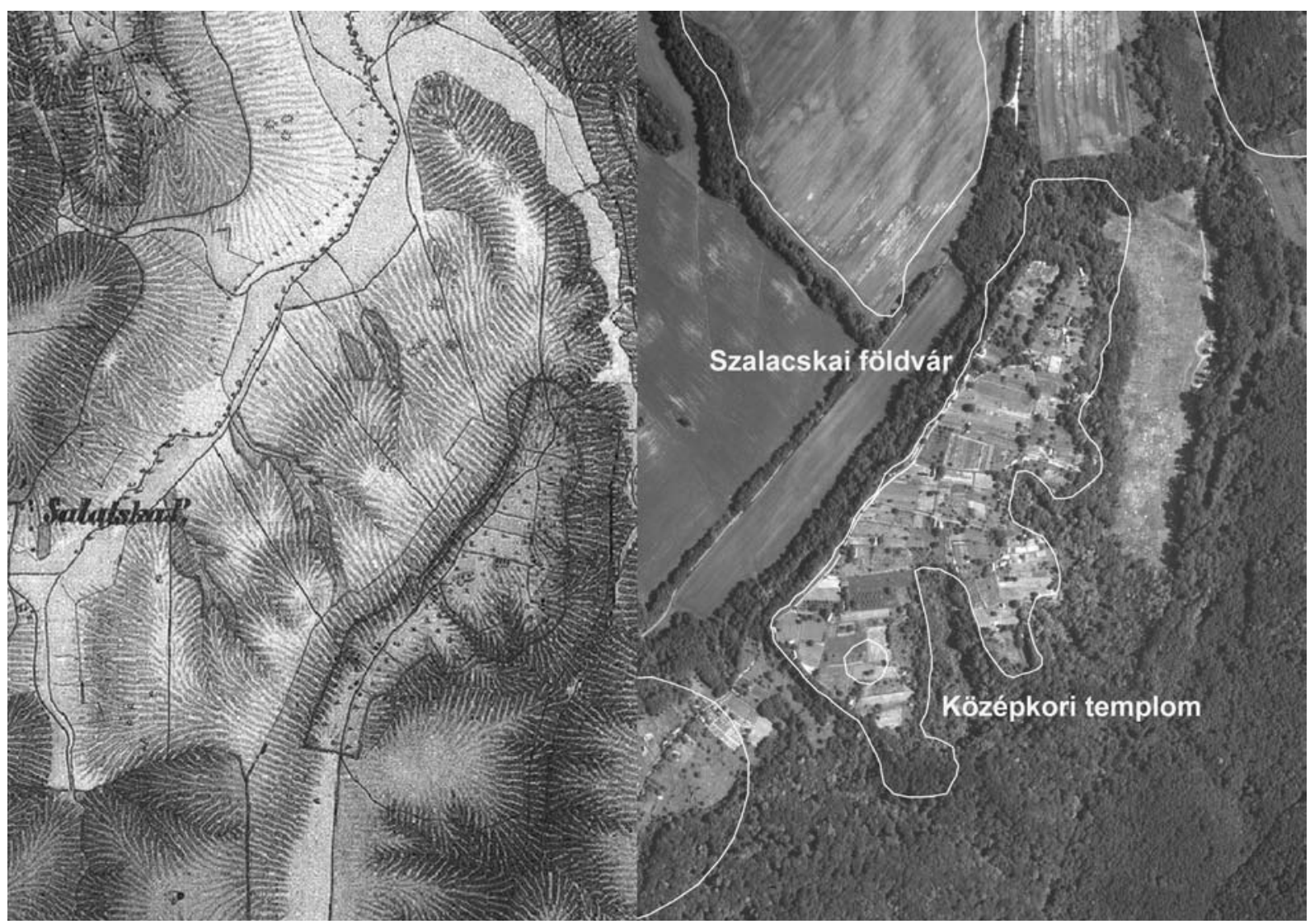

2. ábra: Szalacska-puszta a II. katonai felmérésen és egy müholdképen

készül el, Szent Antal tiszteletére felszentelve - megépítik, nyilván a korábbi templom már nem létezhetett, mert akkor valószínüleg annak a helyén vagy annak a romjaiból emelték volna a kápolnát.

A Somogy megye földrajzi nevei kézikönyv az alábbi adatokat említi: „111. Szalacska-puszta: Szalacskaimajor: Jelenleg a tsz egyik majorjaként üzemel. 134. Vár ajja: a szalacskai földvár alatt húzódik. 152. Kápolna: Szalacska legmagasabb pontjára épült. 153. Szalacska: Pesty Frigyes szerint régen itt híres vár volt, amelyet Szent István csak 7 évi ostrom után tudott bevenni. 171. Erdőg vára. 172. Csapka teltős, Sapka tőttés: Pesty Frigyes szerint Szent István idejében keletkezett. "27

Több helyen feltünik a Váralja településrész, amit jelenleg még nem tudunk pontosan behatárolni, hogy hol is helyezkedhetett el, de mindenképp egymáshoz közel kellett lenniük. ${ }^{28} \mathrm{~A}$ Somogy megyei vármonográfiában említik Berki-gát vára nevezetű erődítést, amelyet 17. századi forrásokból ismerünk, viszont eddig még nem sikerült azonosítani. Ennek kapcsán Magyar Kálmán megemlíti, hogy ez az erődítés eset-

27 SMFN 484-485., A 153-as pontnál lévő adatra máshol nem találunk hivatkozást, így egyelöre nem tartjuk bizonyítottnak ezt a történetet. A Sapkatöltést (amit eddig még nem sikerült azonosítani) Csánki Dezső valószínünek tartja, hogy a törökök építették. Csánki 1914. 117., Az Erdőg vára elnevezésű hely szintén azonosítatlan még.

28 Erre az adatra K. Németh András hívta fel a figyelmemet. leg kapcsolatba hozható a fentebb említett földrajzi nevek valamelyikével. ${ }^{29}$ Ezt a lehetőséget elöször Papp Sándor vetette fel, aki 2002-ben egy addig ismeretlen török nyelvű dokumentumot ismertetett. ${ }^{30}$ Az irat szerint a palánkot (kastélyt, várat?) a törökök emelték a pécsi szandzsákban, valószínüleg 1655ben. Az 1606-os zsitvatoroki béke értelmében új várat nem lehetett építeni, azonban a törökök azzal védekeztek, hogy nem új várat emelnek, hanem egy régi török palánkot újítanak fel. Miután elkészült 320 főnyi őrséget helyeztek el benne. Egy korabeli beszámoló szerint a palánk a Koppány mellett, a két víz: a Kapos és a Balaton között, nem messze Pécstől volt található. Ezen leírás alapján a palánk akár Nagyberki környékére is helyezhető, de pontos helye nem ismert. A palánkot 1660-ban pusztították el, amikor Ákosházy Sárkány János érszegi fökapitány betört csapataival. Arról, hogy az erődítményt újraépítették volna, egyelöre nincs adatunk.

29 Magyar - Nováki 2005. 163-164.

30 Papp 2002. A német nyelvű iratokban az alábbi formákban szerepel: Perky, Perckhi, Perki, Pereki, Berky, Berki, Bereky, Bereckhy, Berechi. 


\section{A feltárások}

\section{2. évi feltárás ${ }^{31}$}

1982. augusztus 3-tól szeptember 14-ig Honti Szilvia vezetett ásatást a földvár területén. ${ }^{32} \mathrm{Az}$ ásatás célja a korábban részlegesen megtalált kelta éremverő mühely azonosítása és feltárása volt. Az alábbiakban az ásatásokon előkerült középkori objektumokat és leleteket mutatjuk be.

A II. szelvényből került elő egy vas patkó töredéke (96.203.4.) és egy vas ár (96.203.5.).

A IV. szelvény nagyjából kelet-nyugat irányú, mérete 5,5×4 méter (VII. tábla/1-2.). ${ }^{33}$ A szelvényben a felső 70 centiméter leszedése után a vegyes leletanyagból több középkori kerámia is előkerült. 60 centiméter alatt sok paticsdarab került elő, a szelvény keleti feléből pedig, -80-100 centiméter között egy 16-17. századi tollas vasbuzogány (96.209.17.) látott napvilágot. A szelvény felső rétegei egy nagy középkori építményhez tartoznak, alatta két őskori gödör került elő. Az északkeleti sarokban lehetett megfigyelni egy földbeásott középkori gödör egyenletesen lejtő falát. Nagyjából a szelvény közepén egy kelet-nyugat irányú, éles határvonalú „lépcső” választotta ketté a középkori objektumot (14. objektum) (VII. tábla/2.). A szelvény nyugati felében is megtalálható volt az a „lépcső”, amely a déli fal mellett húzódik. A 14. objektum leletanyaga 13-14. századi, valamint sok őskori, többnyire késő bronzkori kerámiák. A szelvény nyugati felében is vegyesen középkori és őskori anyag került elő.

A délkeleti sarokban egy töredékes, „keményfalú” objektum töredéke maradt meg (14/a objektum) (VII. tábla/2.). Esetleg egy tüzhely hamusgödre lehetett, amelynek nagy részét megsemmisítette a 14. objektum. A leletanyagában kerámiákat valamint egy kis hullámvonalas díszítésű fazekat találunk, melyet a 10-11. századra lehet keltezni. Szintén ebböl a szelvényből látott napvilágot egy bronz gyürü (96.209.15.).

$A z$ V. szelvényben - amelyet az előző szelvénytől délebbre jelöltek ki, mérete $2 \times 10$ méter - a szántott föld alatt, paticsszemekkel tarkított fekete föld volt, köztük néhány római kori és 10-11. századi kerámia volt, de többségében őskoriakat lehetett találni.

A VII. szelvényt a VI. szelvénytöl nyugatra jelölték ki, nagysága 4×10 méter. A szelvény közepén két csontvázas sír került elő, közvetlenül a szántás alól, majd ezek után még további temetkezések láttak napvilágot. ${ }^{34} \mathrm{~A}$ sírok a néhány itt talált kerámia alapján a 13-14. századra datálhatóak, és a szomszédban lévő kis középkori templomhoz tartozhattak. A szelvény délnyugati részén újabb sírokat leltek (VI. tábla/1-8.).

31 Az ásatásról rövid jelentés: Honti Szilvia: Nagyberki-Szalacska. Régészeti Füzetek 1. No. 36. 1983. 21.

32 Az ásatások középkori részének feldolgozásáért, valamint a munka során nyújtott hasznos információkért köszönet dr. Honti Szilviának.

33 Nagy Károly földjén, a présháztól mintegy 30 méterre délnyugatra lett kijelölve.

$34 \mathrm{Az}$ 1. számú sír egy római kori temetkezés volt, így ennek ismertetésétöl eltekintek most.
2. sír: Ny-K-i tájolású, nyújtott helyzetü férfi csontváza, karjai a medencén voltak. Melléklete nem volt.

3. sír. Ny-K-i tájolású, nyújtott helyzetü gyermek csontváza, karjai keresztbe téve. Melléklete nem volt.

4. sír: Ny-K-i tájolású, felső része elszántva, mélysége: $-30 \mathrm{~cm}$. Melléklet: a medence tájékán egy vascsat volt.

Az 5-6-7. számú sírok a szelvény nyugati fala alá nyúltak.

5. sír: Ny-K-i tájolású, bolygatott sír, csak a lábszára maradt meg. Melléklete nem volt.

6. sír: Ny-K-i tájolású, gyermek csontváza, koponyája sérült. Melléklete nem volt.

7. sír: az előző két sírtól ÉNy-ra helyezkedik el, NyK-i tájolású, felnőtt férfi lábszára. Melléklete nem volt. Felette újabb csontváz lábujjai, amelyet nem lehetett kibontani már.

8. sír: a 27. objektumba ásva, részben a szelvény fala alá nyúlik. NY-K-i tájolású, nyújtott helyzetű felnőtt csontváza, bal karja a mellkasra hajtva, jobb keze a medencén. Melléklete nem volt, mélysége: $-42 \mathrm{~cm}$.

9. sír: az 5-6-7. síroktól délre került elő. Gyermeksír teljesen feldúlt maradványai.

10. sír. a 2. sír felszedése után bukkant elő, feje a 2. sír medencéje alatt van. Ny-K-i tájolású, a 2. sírtól kissé észak felé eltér. Felnőtt csontváza, melléklete nem volt.

11. sír: a szelvénybe csak a lábcsontjai estek bele. Rábontás után kiderült, hogy csak a lábfej csontjai vannak meg - ez esett a szelvénybe - ebbe ásták a 11 . sírt, mely teljes épségben megmaradt. Ny-K-i tájolású, nyújtott, 2 karja kinyújtva, de a medencére hajlik, feje elfordult, mélysége: $-31 \mathrm{~cm}$.

12. sír. a 11. sír mellett, de attól mélyebben került elő. Ny-K-i tájolású, fiatal nő vagy ifjú csontváza, az előzőnél kisebb csontváza. Karjai egyenesen a test mellé téve. A csontváz hossza lábcsontok nélkül 152 $\mathrm{cm}$, mélység: $-55 \mathrm{~cm}$.

„13. sír”: az ásatás utolsó előtti napján értesítették a régészeket, hogy a közelben egy ásó kiforgatott egy csontvázat. A csontváz tájolása DK-ÉNy volt, mélysége $-60 \mathrm{~cm}$, melléklete nem volt, kora ismeretlen, de valószínü, hogy nem középkori a tájolása miatt.

1982-ben ajándékként került a múzeum gyűjteményébe egy bronz üllő (96.210.1.), amelyet akkor középkorinak határoztak meg (3. ábra).

\section{3. évi feltárás ${ }^{35}$}

1983. augusztus 17. és október 3 . között tovább folytak az ásatások a földvár déli részén, szintén Honti Szilvia vezetésével. A kelta, kora-vaskori, Hallstatt-kori, valamint késő-bronzkori objektumok és leletanyag mellett mindössze egy 13-14. századi gödörkomplexum lett feltárva.

$X$. szelvény: az $\mathrm{V}$. szelvénytöl dél-délkeletre helyezkedett el, mérete: $3 \times 15$ méter. Az első ásónyomban föleg kelta kori kerámia, valamint urnamezős kultúra,

35 Az ásatásról rövid jelentés: Honti Szilvia: Nagyberki-Szalacska. Régészeti Füzetek 1. No. 37. 1984. 20. 

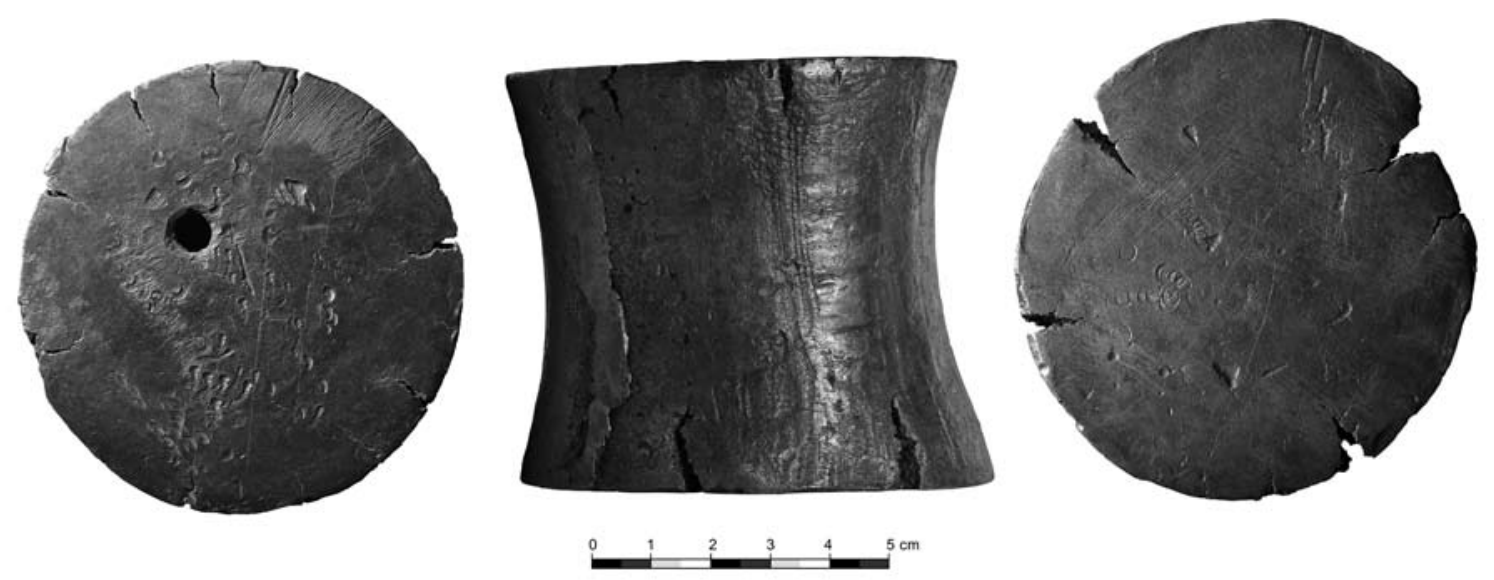

3. ábra: Bronz üllő (fotó: Balla Krisztián)

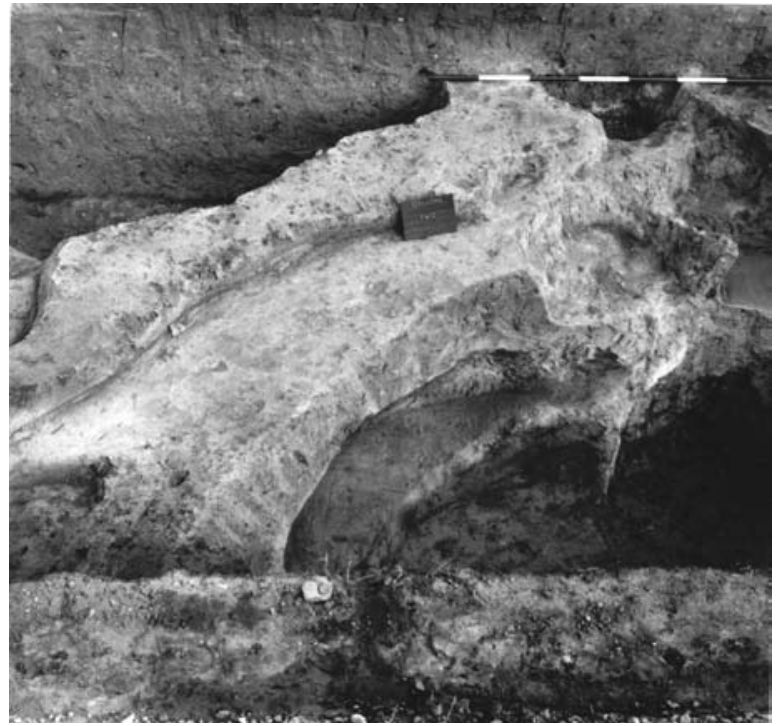

4. ábra: 46. objektum, középkori verem (fotó: Honti Szilvia)

kora vaskori, de néhány középkori kerámia is elökerült (valamint egy vas késnyél vég is elökerült, leltározatlan). A második ásónyomból is volt középkori kerámia, valamint vasszeg. A harmadik ásónyomban már nem volt középkori leletanyag.

$X I$. szelvény: a X. szelvény keleti folytatásaként lett megnyitva, mérete: $3 \times 15$ méter. Az első ásónyomból késő kelta, urnamezős-, Hallstatt-kori, és néhány római kori valamint középkori kerámia került elő. 46. objektum (4. ábra): több objektum egymásba ásásából jött létre, amely egy összefüggő foltként jelentkezett. Nyesése után 6 különböző objektumot lehetett elkülöníteni. Ebből a 46/a. objektum: erősen faszenes-paticsos betöltésü, függőleges falú, teljesen kerek alakú gödör, gazdag 13-14. századi leletanyaggal, mélysége: -174 centiméter. 46/b. objektum: a 46/a. objektum metszi, talán 10-11. századi vagy középkori, betöltése fekete. Sekély, enyhén lekerekített oldalú, egyenes aljú gödör. A nyeséskor előkerült két darab középkori kerámia a mellette lévő 46/a. objektumból kerülhetett bele. 53. objektum: A felső, a szelvény nyugati falánál végighúzódó délről észak felé lejtő vastag paticsos réteg talán középkori lehetett (a felszínhez közelebb 1-2 középkori kerámia került elö, alatta Hallstatt-kori kerámia volt, de nem sok). Ebben a részben nagy paticsdarabok voltak. Alatta már Hallstatt-kori leletanyag volt.

XII. szelvény: a $X$. szelvénytöl délnyugatra, mérete: $7 \times 3$ méter. Az első ásónyomból, a szelvény keleti feléből urnamezős kultúra, La Tène D kultúra, Hallstatt-kori, valamint 10-11. századi leletanyag is előkerült. A második ásónyomban ez utóbbi már nem volt megtalálható.

\section{4. évi feltárás ${ }^{36}$}

1984-ben tovább folytak az ásatások Honti Szilvia vezetésével augusztus 21-től szeptember 15-ig. A késő bronzkori, kora vaskori, kelta kori, római kori objektumok és leletanyag mellett ismét kerültek elő a középkorból is leletek. A XIV. szelvényben előkerült egy nyílt tüzhely, melynek környékén és a tapasztás alatt 10-11. századi kerámiákat találtak. Valamint előkerült még egy mély cölöplyukszerü gödör, amelyben 13-14. századi leletanyag volt.

A XIII. szelvény északnyugati sarkából középkori köpűs nyílhegy került elő. A szelvény nyugati 5 méteréből az első két ásónyomból valószínüleg egy középkori lándzsa látott napvilágot. ${ }^{37}$

A XIV. szelvényben nyeséskor került elő egy tüzhely északi fele, amely a 71. objektum (5. ábra) lett. Az agyaggal tapasztott, átégett platniját kétszer sározták, a sározásban alul kerámiák is voltak. A platni felett közvetlenül és a tüzhely fölötti paticsdarabok között is 10-11. századi kerámiák kerültek elö, amik megadják a tűzhely korát is. A tüzhely alakja ovális, észak-déli irányban. Hosszabbik átmérője 90 centiméter, rövidebbik átmérője 70 centiméter. Mélysége felül 52 centiméter, alul 57 centiméter. Amikor felszedték a tüzhelyet, látszott,

36 Az ásatásról rövid jelentés: Honti Szilvia: Nagyberki-Szalacska. Régészeti Füzetek 1. №. 38. 1985. 20.

37 A leletek hollétéről jelenleg nem tudunk. 


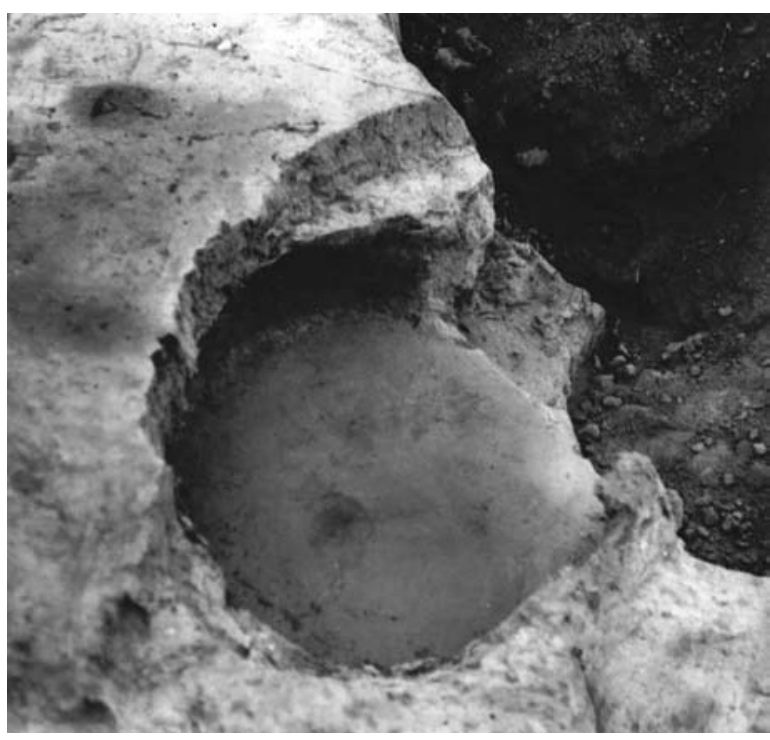

5. ábra: 71. objektum, középkori kemence (fotó: Honti Szilvia)

hogy kettős tapasztású, a korábbi kisebb tűzhely alatt erősen átégett a föld is, tehát sokáig használhatták. A felső tapasztást kerámiákra tapasztották rá, úgy égették ki. 76. objektum amelyet a 77. objektumba ástak bele. Felső rétegei kerek formájúak, lejjebb erősen szélesedik. Kelta kori kerámiák, valamint a 75 . objektum felé eső részéből középkori kerámiák kerültek elő. Alja egyenes és vízszintes, enyhén méhkas alakú gödör, mélysége -183 centiméter

\section{8. évi feltárás ${ }^{38}$}

1988-ban szeptember 6-29. között zajlottak az ásatások Honti Szilvia vezetésével. A rövid időszak alatt mindössze egy szelvény ( $X V$. szelvény) feltárására került sor, azonban az itt feltárt objektumokból középkori leletanyag nem került elö. Mindössze a 85 . objektum felszínéröl került elő egy darab késő középkori kerámia, amúgy az objektumból sok Hallstatt-kori és La Téne kultúra kerámia került elő. A szelvényt a mai kápolna közelében, attól délkeletre jelölték ki.

\section{9. évi feltárás ${ }^{39}$}

1989-ben augusztus 22. - október 31. között volt ásatás Honti Szilvia vezetésével. Az ásatást a 1983-84. évi szelvényektől keletre jelölték ki.

A XVI. szelvényben került elő a 101. objektum (VII. tábla/4.). Nagyjából észak-déli irányú, kissé szabálytalan, de egyenes oldalú, szürkésbarna betöltésü gödör. Az első ásónyomból közepes mennyiségü őskori kerámia mellett 1-2 darab középkori is elökerült, ez utóbbiak határozzák meg a korát. 40-60 centiméteres mélységről

38 Az ásatásról rövid jelentés: Honti Szilvia: Nagyberki-Szalacska. Régészeti Füzetek 1. No. 42. 1991. 20.

$39 \mathrm{Az}$ ásatásról rövid jelentés: Honti Szilvia: Nagyberki-Szalacska. Régészeti Füzetek 1. No. 43. 1991. 11 középkori vaspánt került elő. Kitölti a szelvény 0-2 méter közötti részét. Keleti fala közel egyenes és függöleges, metszi a 119., 120., 121. objektumokat. Délkeleti sarkában kissé megtört és egyenetlenné vált a szélének vonala. A 101. objektum alját mindenütt sárga (2-3 centiméter), döngölt lösz fedte, ez teljesen egyenes és vízszintes. Ez a réteg biztos, hogy nem az altalaj volt, mert több objektumot fedett. Ezt a réteget egyszer megújították. A késő középkor-kora újkor határára datálható a benne talált vaseszközök (fúró, vaspánt stb.) alapján. 115. objektum (VII. tábla/3.): kerek, sötétszürke színű betöltésű gödör. Beleásták a 114-es és 116-os objektumba. Sok 14-16. századi kerámia került elő belöle, köztük tojáshéj kerámia is. Fekete, porhanyós humuszos betöltésével jól elvált a környező a 106. és 116. objektumoktól. Különösen a felső rétegeiben volt sok kerámia, többnyire Árpád-kori. A gödör enyhén hasasodik, majd alul összeszűkül, fala lekerekített, alja egyenes. 120. objektum: kerek, lekerekített aljú gödör, mintegy fele esett a szelvénybe, és benyúlott a 101. objektum alá. Ezt is késő középkorra, esetleg a kora újkorra lehet datálni. A benne talált egyik tégla darab római kori is lehet. 121. objektum: nagy löszdarabokkal és fekete-barna földdel egyenetlenül elkeveredett gödör, a 101. objektum alatt került elö, késő középkori (VII. tábla/4-5-6.).

A XVII. szelvényben is folytatódott a 101. objektum, melynek a felszínéröl egy középkori ezüstpénz került elö ${ }^{40}$ (6. ábra). A szelvényben az első ásónyomban 1320 méter között a déli részen került elő középkori anyag. 14 méternél a szelvény közepén egy csontnyelü, bronz végű vaskés került elő (98.72.1) (7. ábra). 13-20 méter között a második ásónyomban, a déli sávban csak középkori leletanyag került elő. Nagyjából ezen a részen kerültek elő a 131., 134., 135. és 136. objektumok. 100 centiméter mélységből 17 méternél egy ezüst denár ${ }^{41}$ (8. ábra) került elő, valószínűleg a 131. objektum betöltéséből. A 131. és 134. objektumok közötti részen sárga lösz és agyagréteg volt megfigyelhető (3-10 centiméter vastag), amely egy középkori „járószint” lehetett. Alatta továbbra is középkori anyag. Ezen a járószinten egy helyen kerek foltban átégett sárga „tapasztás”, amely szabadon álló tüzhely lehetett, és kevés ideig használhatták. 136. objektum: laza, hamus betöltésü, igen meredek falú és mély, -220 centiméteren nem volt meg az alja. Sok vastárgy került elö belöle. 131. objektum: nagy középkori objektum, meredek, lejtős falát vastag agyagréteg, tapasztás (?) borítja, viszonylag vastag sávban. Nagy, lekerekített sarkú, téglalap alakú, illetve szinte ovális gödör. Szájánál kevésbé meredek falú, majd kb. -60 centiméter mélységtől fala jóval meredekebben zuhan le. Úgy tűnik, hogy két szintjét használták, bár a felsőbb vastag agyagréteg inkább betöltési réteg lehetett. Az agyagréteg felett egy szürke réteg volt, ami fölött pedig egy tüzhelyszerü folt, alakja az oválishoz közelítő.

40 V. Albrecht (1411-1439), Ausztria, 1427-39 között Bécsben vert egylapú pfennig, CNA I. F a 6 (Koch 1994.). Ltsz.: 98.70.1., átmérő: 14,08-14,71 mm, súly: 0,40 g.

41 II. Ludovico di Teck pátriárka (1412-1437), Aquileia-i érsekség, 141237 között vert soldo, CNI VI. III. 28., 38. oldal. Ltsz.: 98.76.2., átmérő: 15,70-16,94 mm, súly: 0,44 g. A város ekkor már Velence fennhatósága alatt volt. A két érmét V. Székely György határozta meg. 

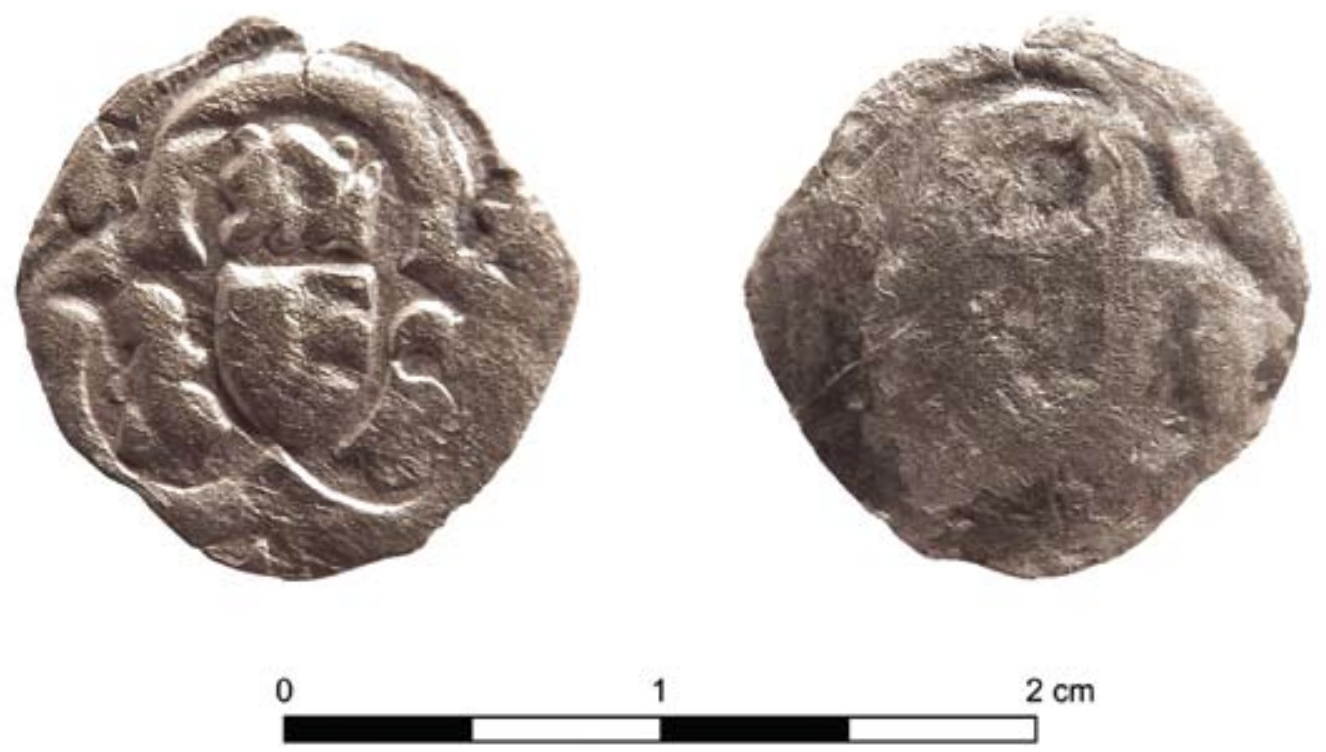

6. ábra: Ezüst bécsi pfennig (fotó: Balla Krisztián)

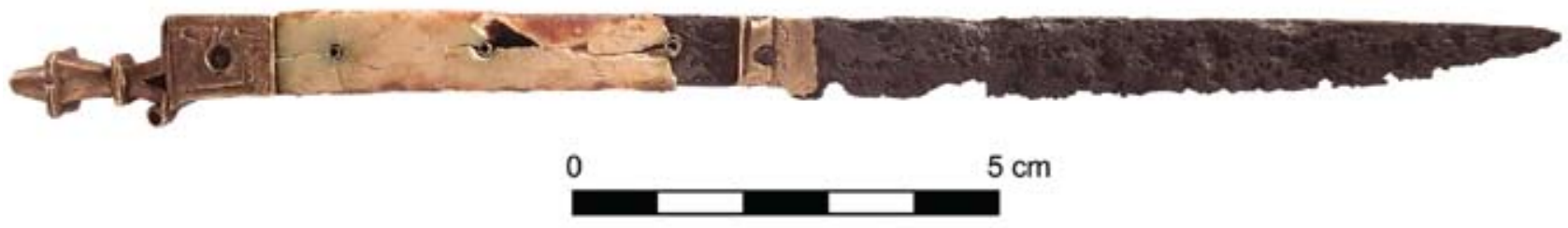

7. ábra: Középkori vas kés, csont nyélborítással és bronz díszítéssel (fotó: Balla Krisztián)
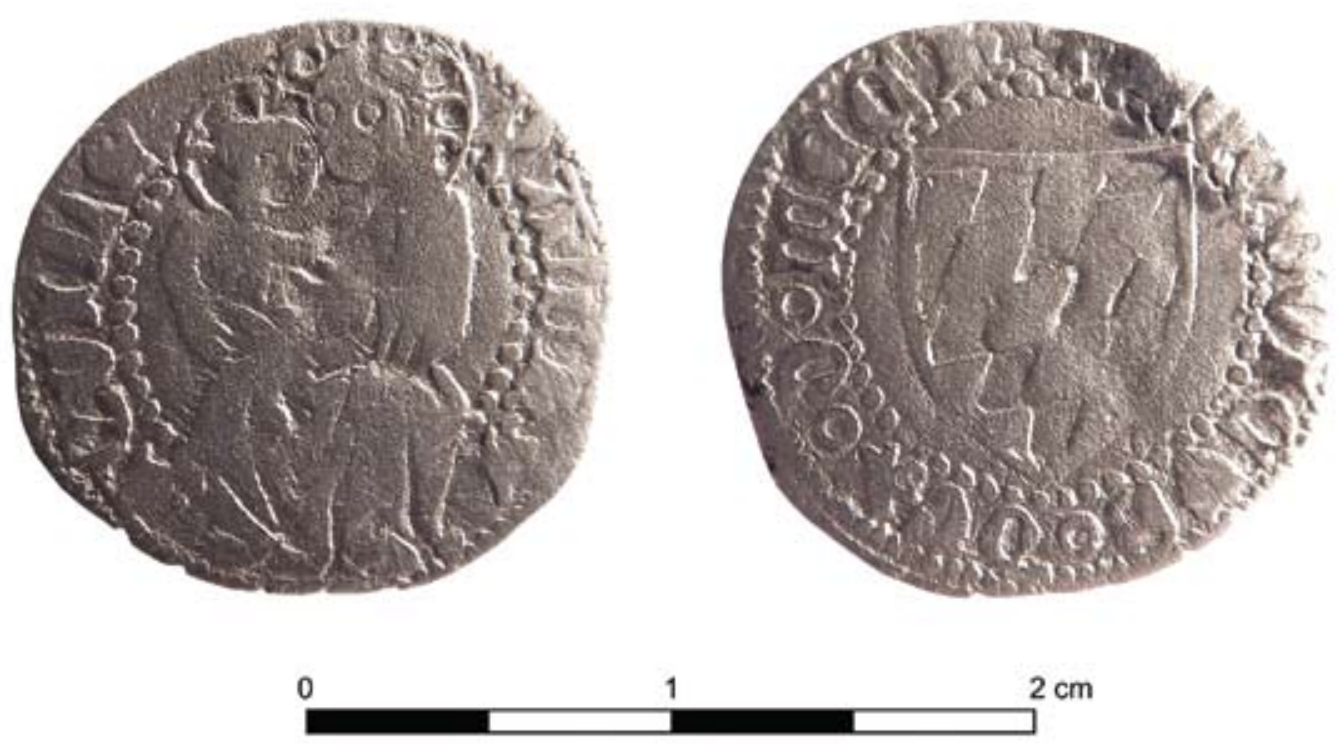

8. ábra: Ezüst aquileiai soldo (fotó: Balla Krisztián) 
Funkciója bizonytalan, vékony paticcsá átégett vörös réteg, alatta hamu volt. Ez a szürke réteg a gödör ferde oldalán is folytatódott, itt összefüggő vörösre égett folt volt, a felszínén vékony fahamu réteg volt. A 131-134. objektumok közötti részen a szelvény közepén két korábbi középkori objektum is volt. 135. objektum: Egy délkelet-északnyugati irányú ovális, meredek falú gödör. 134. objektum: egy nagy késő középkori gödör, alig nyúlt be a szelvénybe, nem lehetett teljesen kiásni. 136 . $a-b-c$ objektumok: a szelvény délkeleti sarkában több, egymásba ásott középkori objektum. A legfiatalabb az „a” jelü, amit a két méhkas alakúba (b-c) ástak bele.

XVI. szelvényből előkerült leletek: 101. objektum: vas kés (98.69.1.), vas eszközök (98.69.2-3-4.), vas fúró (98.69.5.).

A XVII. szelvényböl az alábbi leletek láttak napvilágot: 131. objektum: vas kapocs (98.75.7.), vas sarkantyú (98.75.1.), vas tárgy (98.75.3.), vas kés (98.75.6.), vas szeg (98.75.2., 98.75.4., 98.75.5.); 131-134. objektumok felett: vas szeg (98.76.1.), vonókés (98.76.3.); 134. objektum: vas sarló (98.77.1.), vas tárgy (98.77.2), vas szeg (98.77.4.), vas tárgy (98.77.5.), vas kés (98.77.6.); 136/a. objektum: vas tárgy (98.78.1.), vas sarkantyú (98.78.2.), vas patkó (98.78.3.); humuszból: vas kapocs (98.71.1.), vas kés bronz véggel (98.72.1.), vas tárgy (98.73.1.), bronz lemez (98.74.1., szórvány), vas tárgy (98.77.7.)

Ugyanebből a szelvényből három darab leltározatlan üvegtöredék (oldaltöredékek, aljtöredék), valamint szintén egy leltározatlan üvegtöredék (ívelt aljtöredék, serleg?) az ásatástól délkeletre.

\section{Katalógus-Tárgyleírás ${ }^{42}$}

Kaposváron a Rippl-Rónai Múzeumban lévő leletek:

73.162.1-10.:kerámialeletekNagyberki-Szalacskáról, melyet Kiss Ferencné földjén találtak szőlőforgatáskor, 1972. március 24-én vették át, és Draveczky Balázs gyüjtése ${ }^{43}$. Ezek közül, ami a leltárkönyvben középkoriként szerepel: 73.162.1. és 73.162.10.44

74.219.1-84.: vegyes leletek vegyes korszakokból Szalacska-Várhegy megjelöléssel. Berzy Péter ajándéka, 1973. április 17-i dátummal.

8846.: Béklyó: Vasból készült, egy nagyjából U-alakú rész van összekötve öt darab szabálytalan és nem egységes méretü láncszemekkel, amelyhez a másik végén szintén egy $U$ - alakú, de az előzőnél nagyobb rész csatlakozik. Utóbbi rész töredékes, feltehetően korábban egy zárszerkezet is tartozhatott hozzá. A kisebb $U$ alakú részről egy, míg a láncszemekről szintén egy kerek láncszem lóg le. Valószínüleg a tárgyhoz tartozhatott még egy láncszem, valamint kettő bizonytalan rendeltetésű vaspánt. Késő középkor/kora újkor

42 Az objektumokból előkerült viszonylag nagyobb mennyiségü kerámiaanyag bemutatása egy későbbi tanulmányban fog megtörténni. Itt csak egy táblán közlünk néhány jellegzetesebb darabot (III. tábla).

43 RRM Régészeti Adattár IV/47/51. Kiss Ferencné területén szőlő aláforgatás közben bronzkori és vaskori jellegű edénytöredékek kerültek elö.

44 Valójában csak a 73.162.10. leltári számú középkori lelet
51.6.4.: Vas csákány vagy kalapács: A leltárkönyvbe rómaiként van bejegyezve, de a középkori leletek között található. Ajándékba kapta a múzeum 1950-ben, de 1931-ben találták. ${ }^{45}$ (IV. tábla/2.)

73.162.10.: Edény peremtöredéke: Sárgásbarna színű, homokkal soványított, jól égetett, kihajló, legömbölyített peremmel. H: 9,1 cm, sz: $3,2 \mathrm{~cm}$, v: 0,7-1,1 cm. 10-11. század (II. tábla/1.)

74.219.56.: Fazék peremtöredéke: Világosbarna, néhol szürke színü, homokkal soványított, rosszul égetett, kihajló, ferdén levágott peremmel. A perem alatt, az edény vállán körbefut egy körömmel benyomkodott minta. H: $14 \mathrm{~cm}, \mathrm{sz}: 5,8 \mathrm{~cm}, \mathrm{v}:$ 0,4-0,6 cm. 11-12. század (II. tábla/2.)

74.219.58.: Fazék peremtöredéke: Erösen kormos, és másodlagosan megégett, homokkal soványított, jól égetett, enyhén kihajló, ferdén levágott peremmel. $\mathrm{H}$ : $6,3 \mathrm{~cm}, \mathrm{sz}: 5,5 \mathrm{~cm}, \mathrm{v}:$ 0,4-0,6 cm. 11-12. század (II. tábla/3.)

74.219.60.: Korsó nyaktöredéke: Sárgásbarna színű, homokkal soványított, jól égetett, függőleges nyakú, a szája tölcsérszerüen kiszélesedik. A pereme enyhén befelé hajlik, legömbölyített. A perem alatt, a nyakon, a külső oldalon egy éles borda fut körbe. M: $8 \mathrm{~cm}$, szá: 4,5 cm, v: 0,4-0,7 cm. 13-14. század (II. tábla/4.)

74.219.61.: Fazék peremtöredéke: Sárgásbarna, néhol szürke színű, homokkal soványított, jól égetett, erősen kihajló, enyhén megvastagodó, és legömbölyített peremmel. H: 6,8 cm, sz: 4,2, v: 0,6-0,9 cm. 11-12. század (I. tábla/1.)

74.219.62.: Fazék peremtöredéke: Sárgásbarna színü, a külső felén kormos, homokkal soványított, roszszul égetett, erösen kihajló szögletes peremmel. H: 3,8 cm, sz: 3 cm:, v: 0,3-0,6 cm 14-15. század

74.219.63.: Fazék peremtöredéke: Szürke színü, enyhén kihajló, vízszintesen levágott peremmel. H: 3,6 cm, sz: $2,7 \mathrm{~cm}, \mathrm{v}: 0,6 \mathrm{~cm}$. 13-14. század (I. tábla/2.)

74.219.64.: Fazék oldaltöredéke: Szürke színű, homokkal soványított, jól égetett, vízszintesen körbefutó négyzet alakú bepecsételésekkel. $\mathrm{H}: 2,3 \mathrm{~cm}$, sz: 2,1 $\mathrm{cm}$, v: 0,6 cm. 12-13. század

74.219.65.: Edény oldaltöredéke: Kívül világoszöld, belül sötétzöld mázas, homokkal soványított, jól égetett edény oldaltöredéke. $\mathrm{H}: 2,6 \mathrm{~cm}, \mathrm{sz}: 3,5 \mathrm{~cm}$, v: $0,4 \mathrm{~cm}$. 16-17. század (I. tábla/11.)

74.219.72.: Fazék peremtöredéke: Sárgásbarna színű, homokkal soványított, jól égetett, erősen kihajló, legömbölyített peremü, fedőhornyos fazék töredéke. H: 3,2 cm, sz: 1,8 cm, v: 0,4-0,6 cm. 12-13. század (I. tábla/7.)

74.219.73.: Fazék oldaltöredéke: Sárgásbarna színű, homokkal soványított, jól égetett, az oldalán vízszintesen körbefutó hullámvonal köteggel, alatta pedig

45 Müller Róbert nem említi a könyvében, de ugyanebben az évben 1931-ben - kerültek elő azok a római kori vasszerszámok, amiket leközöl. Müller 1982. 100-103. Rupnik László (ELTE BTK Régészettudományi Intézet) véleménye alapján kőfaragó szerszám lehetett, és valószínü, hogy a római korból származik. Szintén Müller említ egy sarlót, ami valószínűleg népvándorlás kori esetleg középkori Müller 1982. Kat. 627. 
vonalköteg díszítéssel. A díszítés közvetlenül a perem alatt fut végig, a kihajló peremböl kevés maradt meg. $\mathrm{H}: 2,9 \mathrm{~cm}, \mathrm{sz}: 4,5 \mathrm{~cm}, \mathrm{v}:$ 0,4-0,6 cm. 10-11. század (I. tábla/9.)

74.219.74.: Fazék peremtöredéke: Sárga színű, a külső felén kormos, homokkal soványított, jól égetett, erősen kihajló, legömbölyített peremü, a perem alatt egy gallér fut körbe. $\mathrm{H}: 6,2 \mathrm{~cm}$, sz: $2,4 \mathrm{~cm}$, v: $0,3 \mathrm{~cm}$. 14-15. század (I. tábla/3.)

74.219.75.: Edény peremtöredéke: Világosszürke színü, homokkal soványított, jól égetett, kihajló peremmel, amely enyhén megvastagodik, és enyhén legömbölyített, kis fazék vagy bögre töredéke. $\mathrm{H}: 4,1 \mathrm{~cm}$, sz: $2,7 \mathrm{~cm}, \mathrm{v}$ : 0,4-0,6 cm. 12-13. század (I. tábla/4.)

74.219.76.: Edény peremtöredéke: Szürke színü, homokkal soványított, jól égetett, kihajló vízszintes peremtöredék, melynek egy része behúzott. A perem külső oldalán ujjbenyomkodásos minta, valamint alatta vízszintesen körbefutó vonalköteg. $\mathrm{H}: 4,8 \mathrm{~cm}$, sz: 2,2 cm, 0,6 cm. 14-15. század (I. tábla/6.)

74.219.77.: Fazék peremtöredéke: Sárgásbarna, néhol szürke színű, homokkal soványított, jól égetett, gyorskorongolt, alig kihajló, de megvastagodó, a végén legömbölyített peremmel. H: 4,3 cm, sz: 3,3 cm, v: 0,6 cm. 12-13. század (I. tábla/5.)

74.219.78.: Edény fültöredéke: Halványvörös színü, homokkal soványított, jól égetett, ovális keresztmetszetű fültöredék, kancsó vagy korsó töredéke. $\mathrm{H}: 6,4 \mathrm{~cm}$, sz: 2,1 cm, v: $1 \mathrm{~cm} .14-15$. század (I. tábla/8.)

74.219.79.: Fazék aljtöredéke: Szürke színű, homokkal soványított, jól égetett, fazék aljtöredéke, az alsó felén fenékbélyeggel (kör, benne kereszt). H: 6,2 $\mathrm{cm}, \mathrm{sz}: 3,7 \mathrm{~cm}, 0,5 \mathrm{~cm} .12-13$. század (I. tábla/10.)

74.219.80.: Oldaltöredék. Sárga színü, homokkal soványított, jól égetett, oldaltöredék, egyenesen levágott peremmel, kályhaszem vagy kályhacsempe töredéke, a külső felén részben világoszöld máz. $H: 4,7 \mathrm{~cm}$, sz: 1,8 cm, v: 0,5 cm. 15-16. század (I. tábla/12.)

96.203.4.: Vas patkó: Vas patkó egyik szárának megolvadt töredéke. $\mathrm{H}: 11 \mathrm{~cm}, \mathrm{sz}: 1,3, \mathrm{~cm}$, v: $0,5 \mathrm{~cm}$. 15-16. század

96.203.5.: Vas ár: Téglalap keresztmetszetű vas ár töredéke, az egyik vége laposabb, a másik kihegyesedő. H: 13,5 cm, sz: 0,6 cm. 15-16. század

96.209.15.: Bronz gyürü: Vékony, bronzból készült, körbefutó vájattal díszített gyürü. Átmérő: $2,3 \mathrm{~cm}$, v: 0,2 cm. 14-15. század.

96.209.17.: Buzogány:46 Vas magvú, bronzzal futtatott, hengeres hüvelyü, köpüs, 6 karéjából (tollából) 2 hiányzik, a köpü rész rövid, töredékes. A karéjok között vércsatorna húzódik. A háromszög alakú karéjokon négyszögben elhelyezkedő áttört díszítés. H: 14

46 Jellegzetes magyar fegyverfajta, amelynek ez a típusa a 15-16. században terjed el. A tollak száma 6-14 között változott. A hazai példányokra jellemző, hogy a tollak háromszög alakúak és egyenes élüek, és hengeres vas hüvelyükkel vannak a nyélhez rögzítve. Kalmár 1971. 22-24. 12-13. kép. A tollak áttöréssel való díszítése később lesz divat a 17. században. Kalmár 1971. 26. Egy hasonló darab került elő a fonyódi vár ásatása során, melyet Fitz Jenő vezetett 1958-ban. A fonyódi darabot a 16. századra lehet keltezni. RRM Régészeti Gyüjtemény, leltározatlan darab. cm, sz:11,6 cm, köpü átmérő: 1,7cm. 16-17. század (V. tábla/1.)

96.210.1.: Bronz üllö: Kerek, hasáb alakú, derékban elvékonyodó bronz üllő. Alsó és felső felén egyaránt verésnyomokkal (kisebb bemélyedések), az egyik oldalon furattal, amibe egy kisebb üllöt helyezhettek bele. Az üllő oldala a sok ütéstől repedezett. $M: 7,3 \mathrm{~cm}$, átmérő: 7,5-8 cm. Késő középkor/kora újkor ${ }^{47}$

98.69.1.: Kés: Vasból készült, széles nyéltüskével, ami töredékes, de kettö lyuk van rajta, amiben egy-egy szegecs volt. A penge egyélü, a hegye letörött. Másodlagosan derékszögben meghajlítva. $\mathrm{H}: 13,8 \mathrm{~cm}$, sz: 1,1-1,5 cm. Középkor

98.69.5.: Fúró: Vasból készült, kör keresztmetszetü, a fúró hegye felé elvékonyodó, csavart; a másik vége (nyele) téglalap keresztmetszetű. $\mathrm{H}: 11,1 \mathrm{~cm}$, átmérő: 0,4-0,7 cm Középkor

98.72.1.: Kés: Vasból készült, keskeny, hosszú egyélü kés. A nyelén csontborítással, amelyet három bronz szegeccsel fogattak fel. A borítás az egyik oldalon hiányzik. A nyél és az él találkozásánál bronzpánt található, amin rovátkolt díszítés van. A nyél végén mindkét oldalon bekarcolt díszítésű bronzlemez helyezkedik el, míg a nyél végét vékony bronzlemez fedi, amelyből liliomszerü, több részből összeállított dísz indul ki. H: 17,8 cm, sz: 0,9 cm Középkor (IV. tábla/4.)

98.75.1.: Sarkantyú: Vasból készült, forgóval ellátott, de hiányzik a csillag. A szárai széles ívben hajlanak kifelé, de csak az egyik van meg töredékes állapotban. H: 11,1 cm, sz: $8 \mathrm{~cm}$ 13-15. század (V. tábla/3.)

98.75.3.: Vas tárgy: Hosszú, két szárból álló, a vége felé elvékonyodó, a másik végén ovális, hurkos végü. Ajtó-, vagy ablakpánt. $\mathrm{H}: 12 \mathrm{~cm}$, hurok átmérő: 2,9-3,4 $\mathrm{cm}$. Középkor

98.75.6.: Kés: Vasból készült, széles nyéltüskével, egyenes, egyélü. A nyéltüske töredékes, benne kettő vas szegecs található. H: 13,9 cm, sz: 1-1,6 cm. Középkor

98.76.3.: Vonókés: Vasból készült, nyéltüskés, félkör alakban meghajlított pengéjü vonókés. $\mathrm{H}: 8,6 \mathrm{~cm}$, sz: $3,5 \mathrm{~cm}$. Középkor (IV. tábla/3.)

98.77.1.: Sarló: Vasból készült, keskeny, kiszélesedő, nyéltüskés, félkörívben hajló sarló töredéke. H: 13,3 cm, sz: 1,4 cm. Középkor (IV. tábla/1.)

98.77.2.: Vas tárgy: Vasból készült, téglalap alakú, a felső felén mindkét oldalon egy-egy nyúlvány, töredékes. H: 2,6 cm, sz: 4,2 cm. Középkor

98.77.6.: Kés: Vasból készült, középső, keskeny nyéltüskés, egyélü. Széles pengéjü, a nyéltüske, és a kés hegye is letörött. Másodlagosan derékszögben meghajlítva. H: 10,1 cm, sz: 1,6 cm. Középkor

98.78.1.: Vas tárgy. L alakú, a két szár találkozásánál egy kerek lyuk található. Ajtó-, vagy ablakpánt. $\mathrm{H}$ : $5,7 \mathrm{~cm}, \mathrm{sz}: 4,5 \mathrm{~cm}$, kör átmérő: $0,7 \mathrm{~cm}$. Középkor

98.78.2.: Sarkantyú: Vasból készült, forgó, 6 ágú csillaggal ellátva. A sarkantyúnak csak az egyik szára maradt meg töredékesen. $\mathrm{H}: 8,8 \mathrm{~cm}$, sz: $4,6 \mathrm{~cm}$, csillag átmérője: kb. 4,5 cm 13-15. század (V. tábla/4.)

47 A kora bizonytalan, mivel nem objektumból került elő, hanem ajándékként került be a múzeumba 1982-ben. 
98.78.3.: Patkó: Vasból készült, kisméretű patkó félbetört darabja. A szár végén alul egy „sarkantyú” szerü rész. A sarkantyú tetején egy négyzetes fejü szeg maradt benne a sarkantyúban. $\mathrm{H}: 11,1 \mathrm{~cm}, \mathrm{sz}: 1,5-2,8 \mathrm{~cm}$. 13-15. század (V. tábla/2.)

\section{Összegzés}

Nagyberki-Szalacska a történeti és régészeti irodalomban jól ismert, azonban középkori történetéröl eddig nem sokat tudtunk. Korábban csak néhány szórvány lelet került be a múzeumba. Az 1980-as években megindult tervszerü régészeti kutatásoknak is köszönhetően azonban nagyobb számban kerültek elő régészeti objektumok és leletek. Az eddig összegyüjtött adatok és feldolgozott leletek alapján elmondható, hogy Szalacska feltehető- en már a honfoglalás ideje után benépesülhetett, majd egészen a török kor végéig lakott település volt. Bár írott forrásokkal csak a 16. századtól kezdve rendelkezünk, valószínű, hogy a falu a 10. századtól folyamatosan müködött. Templomáról nincs biztos adatunk, de feltételezhető, hogy a szalacskai várhegy déli oldalán feküdt, ahol középkori sírok is előkerültek. Szintén nincs adatunk arra, hogy az őskori földvárat a középkorban (újkorban) is erődítésként használták volna, bár utóbbira több dolog is utalhat: viszonylag nagyobb számú, katonasághoz köthető leletek (buzogányok, sarkantyúk, nyílcsúcsok), valamint a Berki-gát vára nevezetü erődítés, amelyet eddig nem sikerült lokalizálni, de lehetségesnek tartjuk, hogy a szalacskai szőlőhegyen keresendő. Jelenleg számos bizonytalan pont található még, ezért további kutatások szükségesek még ezek felderítésére.

\section{Irodalom}

CNI VI: Corpus Nummorum Italicorum. Volume VI., Roma, 1922.

CsÁNKı D. 1914: (szerk.): Magyarország vármegyéi és városai. Somogy megye. Budapest, é.n.

FRECH J. 2006: Nagyberki életrajzi lexikon, 1725-2005. Kaposvár, 2006.

K. Németh A. 2011: A középkori Tolna megyei templomai. Pécs, Publikon Kiadó, 2011

KALMÁR J. 1971: Régi magyar fegyverek. Budapest, Natura Kiadó, 1971.

KÁLDY-NAGY GY. 1960: Baranya megye XVI. századi török adóösszeírásai (MNyTK 103.). Budapest, 1960.

KocH, B. 1994: Corpus Nummorum Austriacorum. Band I. Mittelalter. Wien. 1994

Kocztur É. 1964: Somogy megye régészeti leletkatasztere. Régészeti Füzetek. Ser. II., 13., Magyar Nemzeti Múzeum, Budapest, 1964.

MAGYAR K. és NovÁKı GY. 2005: Somogy megye várai a középkortól a kuruc korig. Kaposvár, 2005.
MülLER R. 1982: A mezőgazdasági vaseszközök fejlödése Magyarországon a késővaskortól a törökkor végéig. Zalai Gyűjtemény 19., Zalaegerszeg, 1982.

NÉMETH P. 1964: Emlékezés Darnay Kálmánra (1864-1945). Veszprém Megyei Múzeumok Közleményei 2. (1964) 5-19.

PAPP S. 2002: Egy dél-dunántúli török palánk: Berkigát. In: A hódoltság régészeti kutatása. Opuscula Hungarica III. Szerk.: Gerelyes Ibolya - Kovács Gyöngyi, Budapest, 2002. 129-136.

SMFN: Somogy megye földrajzi nevei. Szerk.: Papp László - Végh József, Akadémiai Kiadó, Budapest, 1974.

SöRös P. és REZNER T. 1905: A Pannonhalmi Föapátság története III. Budapest, 1905.

SZAKÁLY F. 1998: Ami Tolna vármegye középkori okleveleiből megmaradt (1314-1525). Szekszárd, 1998.

TimÁR Gy. 1976: XVI. századi rovásadó összeírások a mai Baranya területéröl. Baranyai Helytörténetírás 1974-75 (1976) 21-94. 


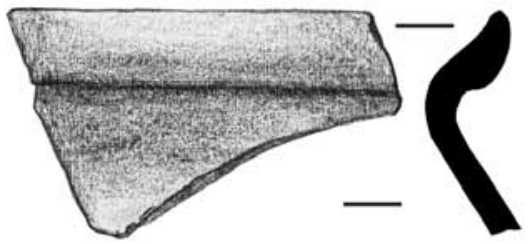

1

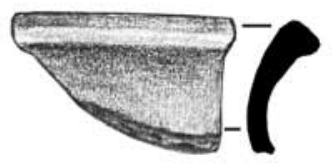

4

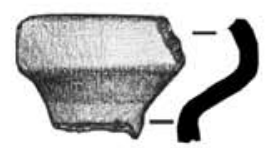

7

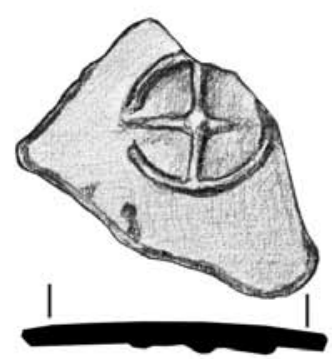

10

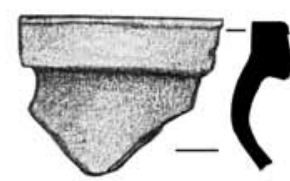

2

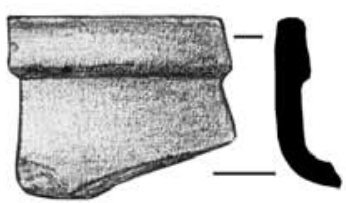

5

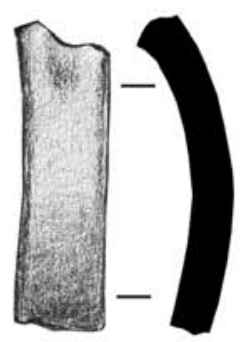

8

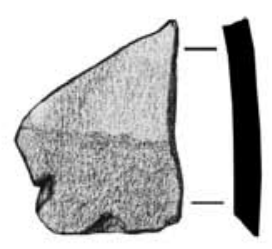

11

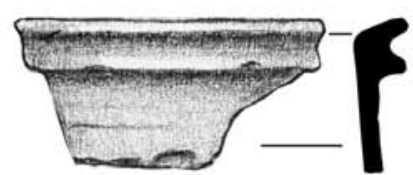

3

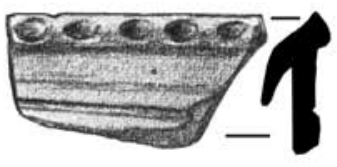

6

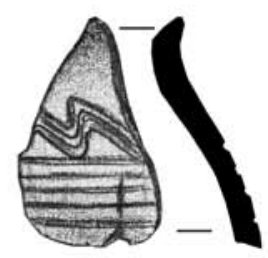

9

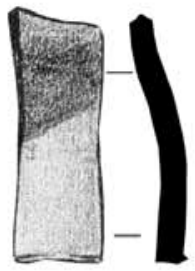

12 


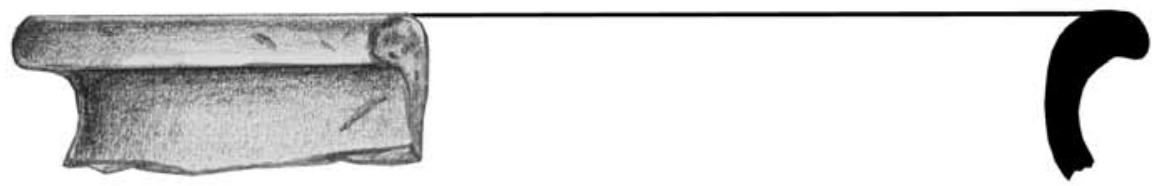

1
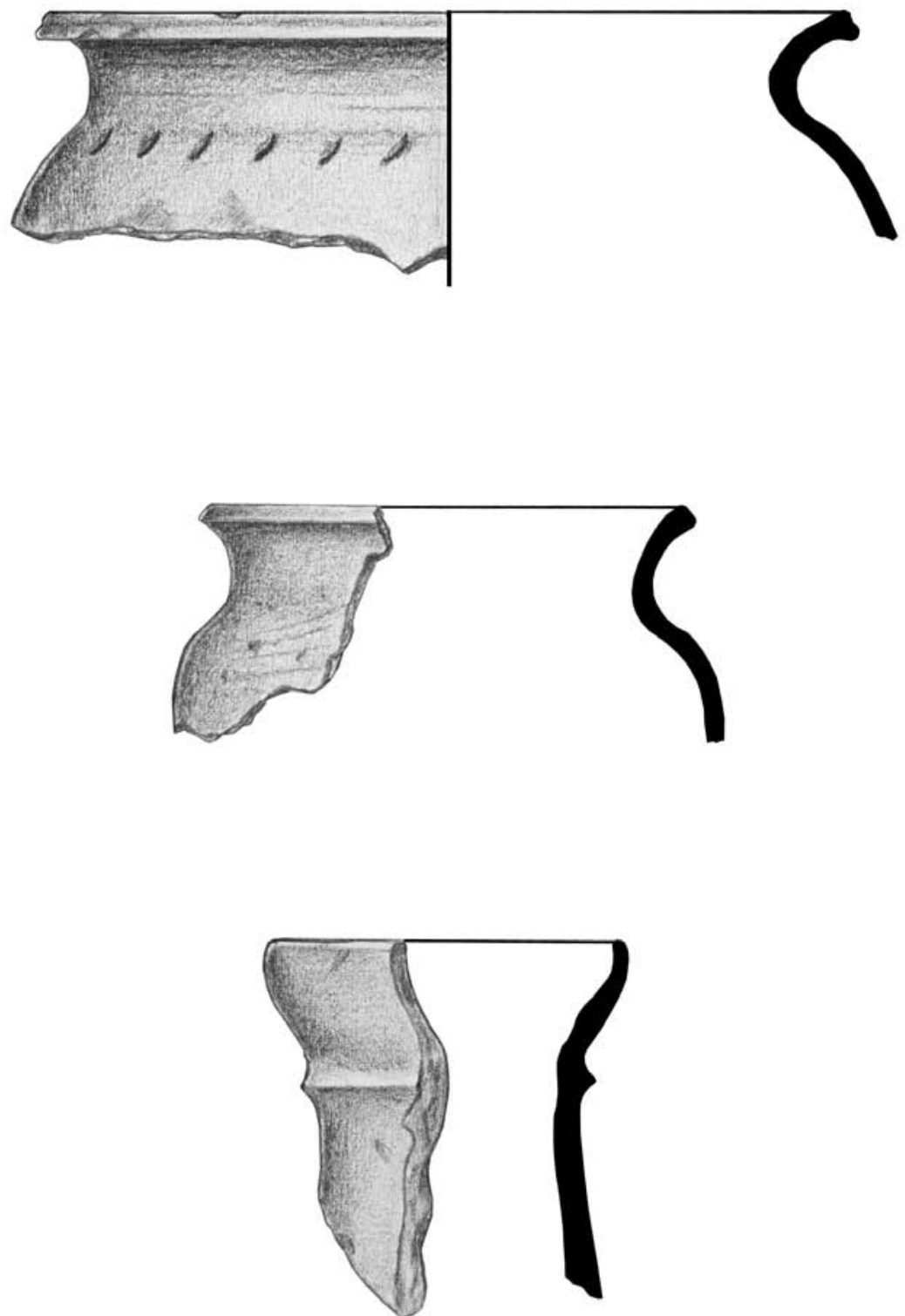

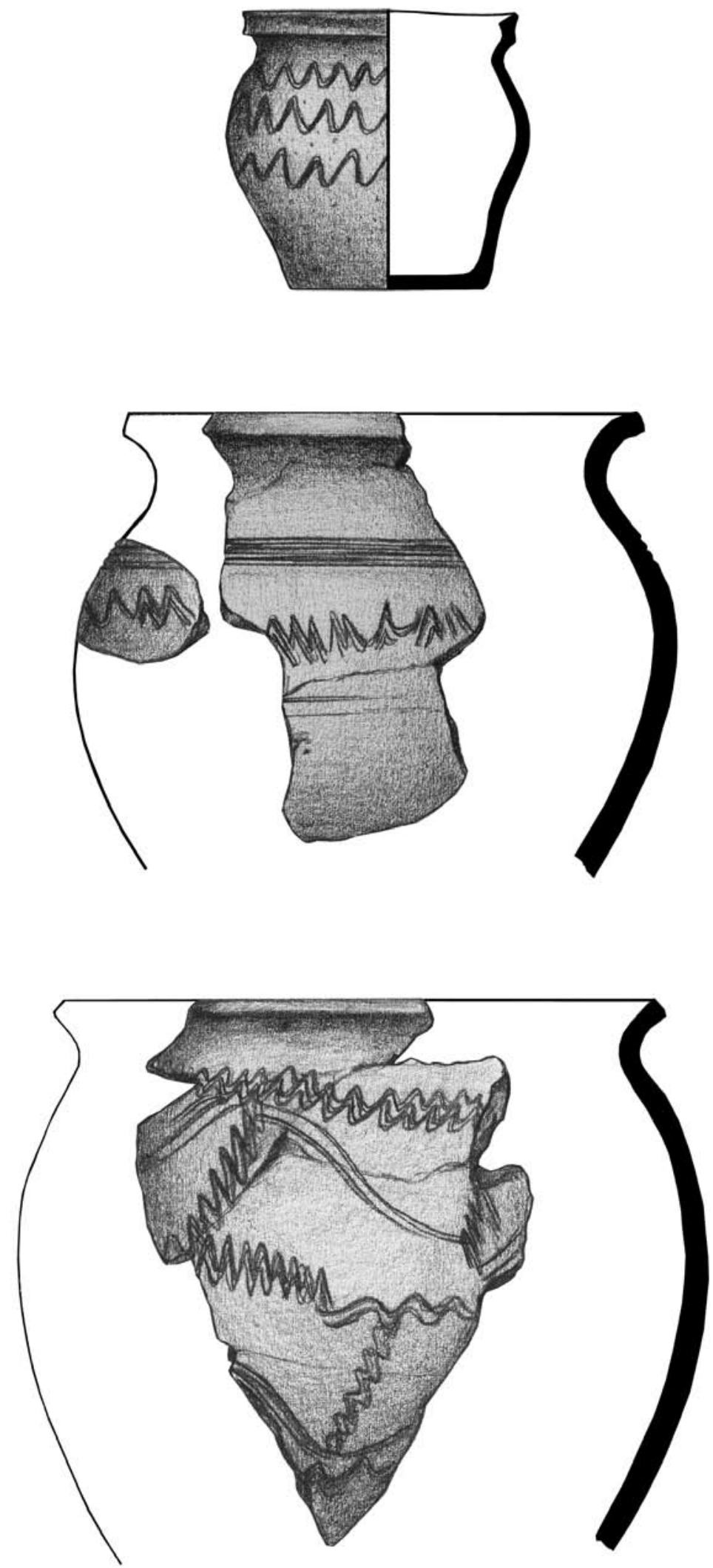

III. tábla: Kora Árpád-kori kerámiák (rajz: Nyári Zsolt) 


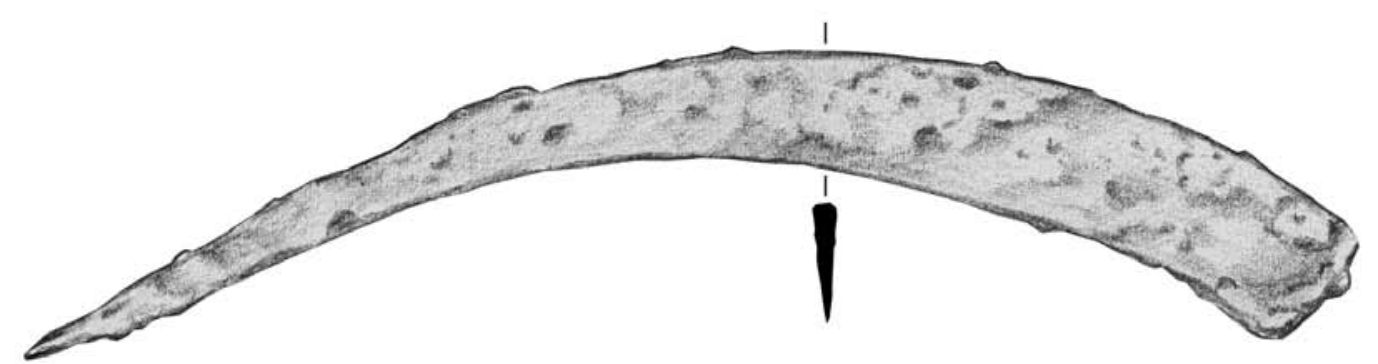

1

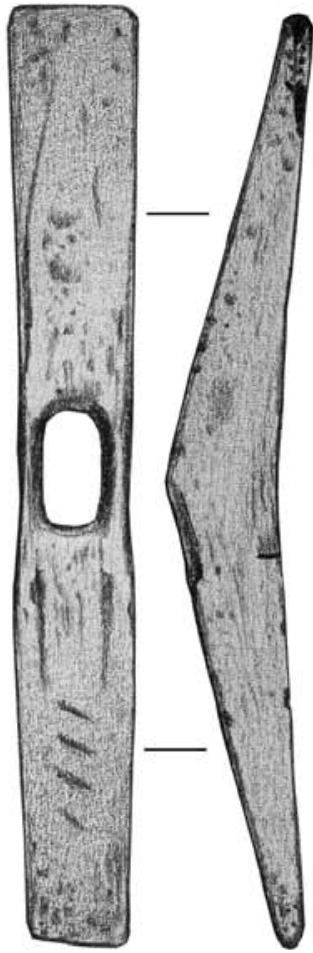

2

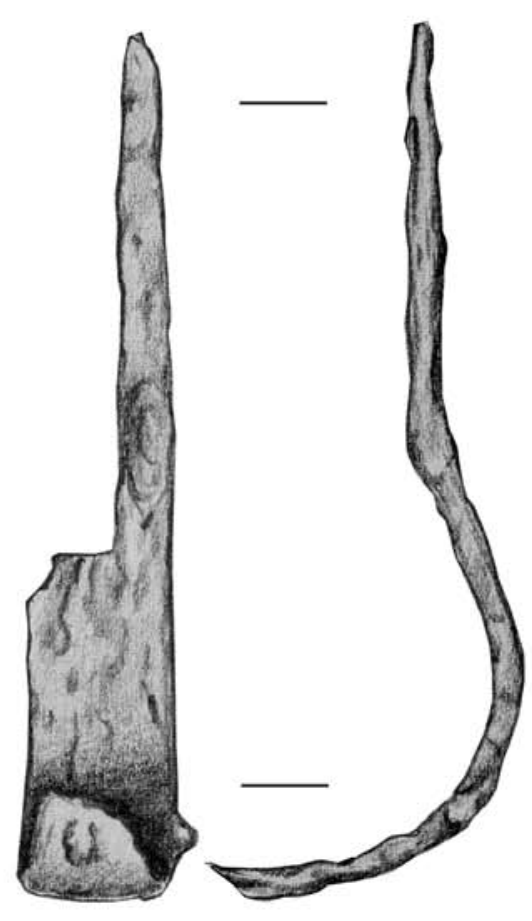

3

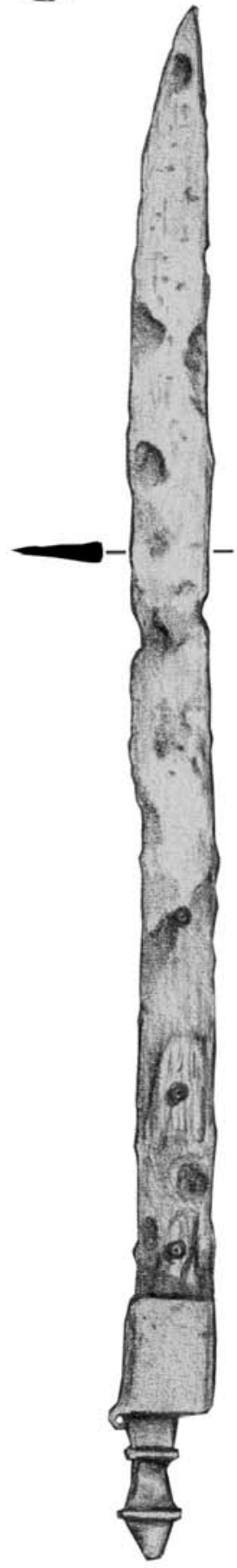

IV. tábla: Középkori vastárgyak (rajz: Nyári Zsolt) 

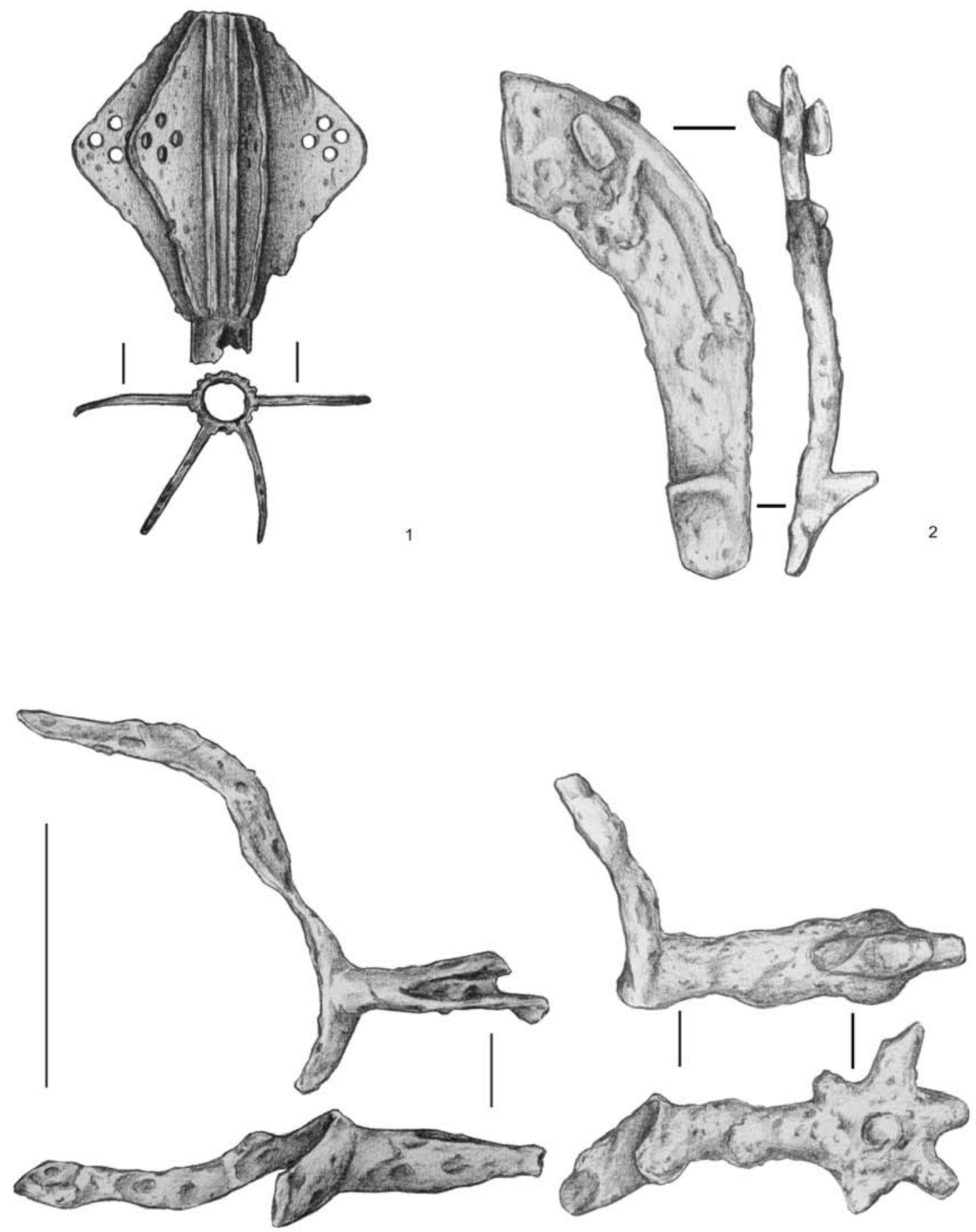


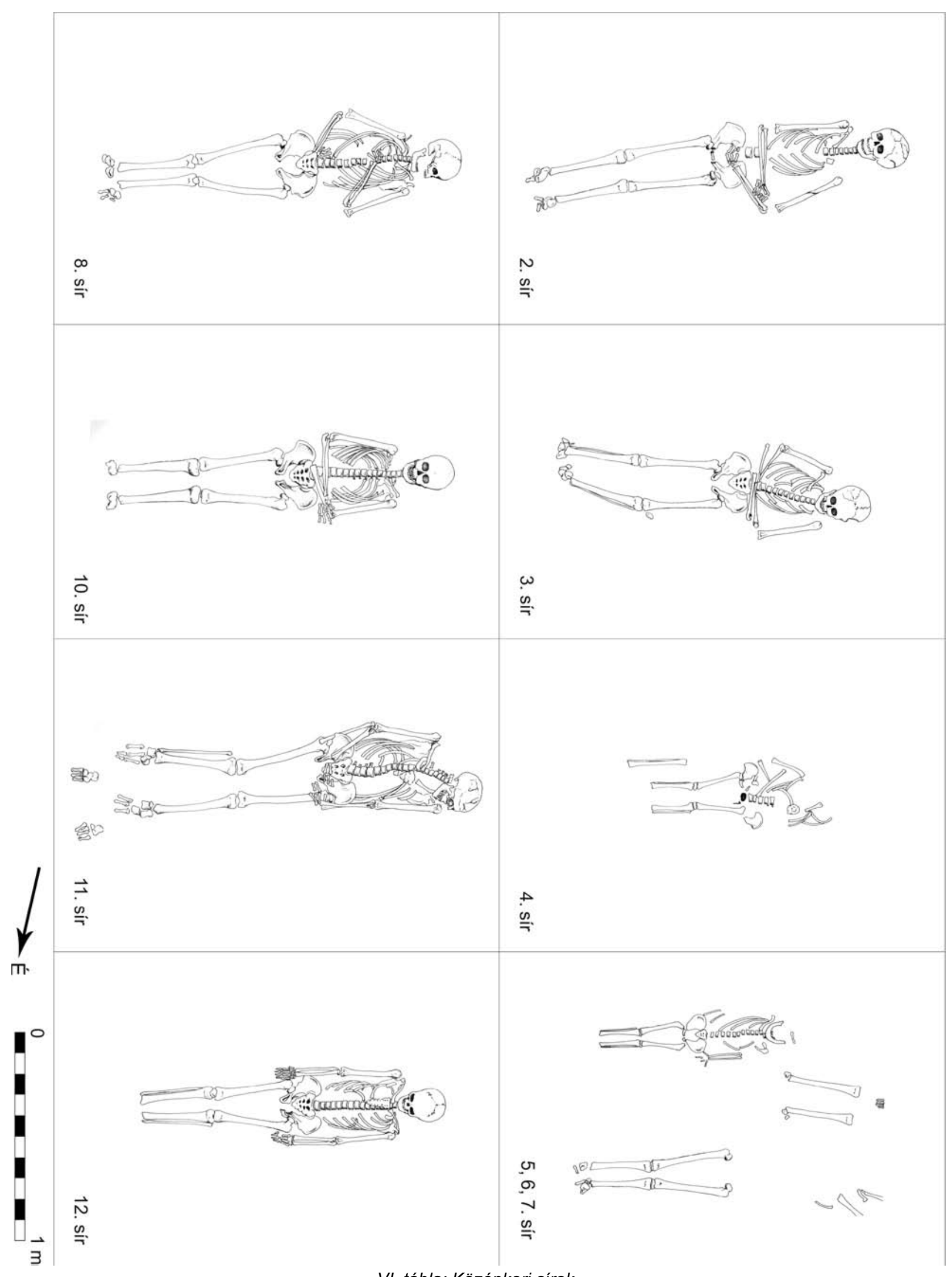




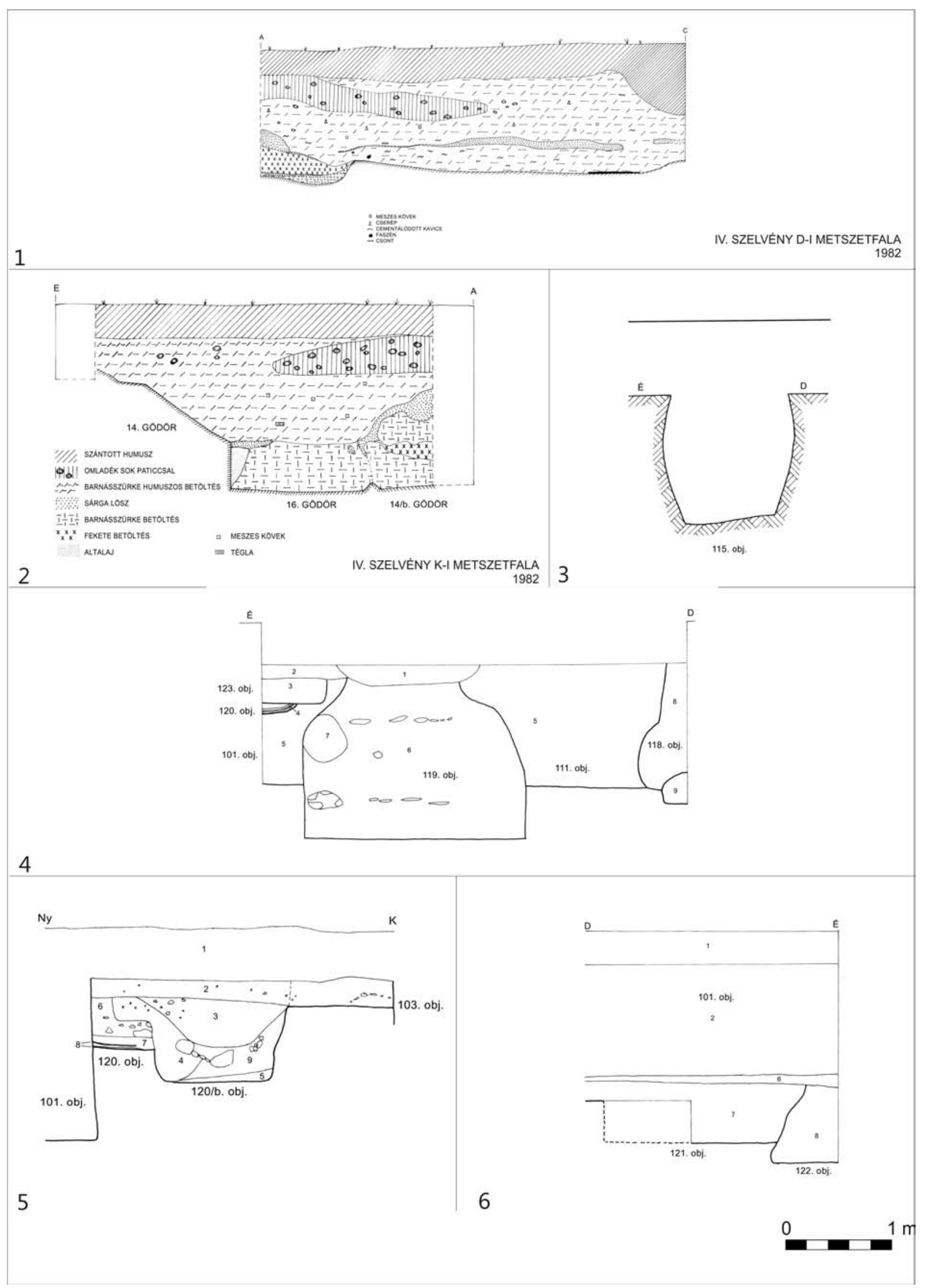




\title{
Mittelalterliche Funde aus Nagyberki-Szalacska I.
}

\author{
MÁTÉ VARGA
}

Nagyberki-Szalacska ist durch die archäologische und historische Literatur gut bekannt, über seine mittelalterliche Geschichte wissen wir aber nicht viel. Früher hat das Museum nur wenige Streufunde erhalten. Dank der in den 1980-er Jahren begonnenen systematischen Ausgrabungen ist aber eine grössere Zahl von archäologischen Objekten und Funden aufgetaucht. Anhand der bis heute zusammengesammelten Daten und verarbeiteten Funden kann man feststellen, dass Szalacska wahscheinlich schon seit der ungarischen Landnahme bevölkert war und blieb dann bis Ende der Zeit der türkischen Annexion als bewohnte Siedlung erhalten. Obwohl schriftliche Quellen nur ab dem 16. Jahrhundert vorliegen, es ist zu vermuten, dass das Dorf seit dem 10. Jahrhundert existierte. Über seine
Kirche kennen wir keine sicheren Angaben, aber wahscheinlich war sie auf der Südseite des Burgberges gelegen, wo auch mittelalterliche Gräber angefunden wurden. Auch dazu liegen uns keine Angaben vor, ob die vorzeitliche Wallanlage auch im Mittelalter (oder sogar in der Neuzeit) als Befestigung genutzt gewesen wäre, obwohl mehrere Zeichen darauf hinweisen: zahlreiche Funde, die zum Militär gebunden sein können (Keulen, Sporen, Pfeilspitzen) bzw. die sogenannte "Burg von Berki-Damm” - die bislang nocht nicht lokalisiert werden konnte aber vermutlich in der Nähe von Szalacska gelegen war. Zur Zeit gibt es noch zahlreiche unsicheren Punkte, zu deren Aufklärung noch weitere Forschungen erforderlich sind. 